\title{
El posthumanisme, un repte educatiu alhora que pedagògic
}

\author{
Miquel Amorós Hernández * \\ Àlex Egea Andrés * \\ Ferran Sánchez Margalef ${ }^{* * *}$ \\ Jordi Garcia Farrero *
}

\section{Resum}

Malgrat pot semblar agosarat, es podria afirmar que la humanitat es troba davant d'un fet inèdit. Per primer cop a la història, les diferents àrees del saber poden confluir i trobar punts d'interconnexió i acabar superant els lligams establerts per les coordinades biològiques i culturals que, fins ara, han delimitat la condició humana. A saber, les diferents ciències naturals, la neurociència, les ciències de la informació, la robòtica, l'urbanisme, la biologia, etc., gràcies a l'avenç tecnològic i la digitalització construeixen una cosmovisió capaç de somiar utopies fins ara irrealitzables. Paradoxalment tot això, que obre moltes oportunitats, planteja alhora moltes qüestions ètiques i deixa la porta oberta a nous reptes pedagògics. El present escrit intenta establir algunes de les línies prioritàries que enceta el posthumanisme, des del punt de vista filosòfic i antropològic, però també des del vessant pedagògic i educatiu.

\section{Paraules clau}

Biologia de l'educació, transhumanisme, posthumanisme, Filosofia de l'educació, Pedagogia

Recepció original: 31 de juliol de 2020

Acceptació: 18 de setembre de 2020

Publicació: 1 de juliol de 2021

\section{Introducció}

L'humà és aquell ser que neix sense determinar. Aquest fet no passa desapercebut puix és precisament la seva indefinició un dels trets més característics de la seva condició, juntament amb la racionalitat, la qual li atorga la capacitat d'auto-determinar-se. No obstant, la pregunta és fins a quin punt pot arribar aquesta capacitat de decidir sobre la seva pròpia naturalesa o sobre el seu propi destí. On són els límits de l'autodeterminació, com a individu i com a espècie? En qualsevol cas, aquestes qüestions no són menors. I no ho són justament perquè les recents investigacions poden posar en escac la idea mateixa de ser humà així com el que forma part de la seva essència o de la seva quotidianitat.

Davant aquests fets, es podria dir que la humanitat s'ha situat en un nou llindar. L'aplicació de les anomenades NBIC (nanotecnologies, biotecnologies, informàtica i cognitivisme) pot acabar superant els trets biològics i culturals que, fins ara, han definit la condició humana. La utilització sistemàtica d'aquests avenços científic-tecnològics ens endinsen en un nou paradigma que posa de relleu, per una banda, la vulnerabilitat i la fragilitat de l'ésser humà i, per l'altra, la seva il.limitada potencialitat física i mental. I això és

(*) Professor del Departament de Teoria i Història de l'Educació de la Facultat d'Educació de la Universitat de Barcelona. Membre del GREPPS (Grup de Recerca en Pensament Pedagògic i Social). Adreça electrònica: miquelamoros@ub.edu

(**) Professor del Departament de Teoria i Història de l'Educació de la Facultat d'Educació de la Universitat de Barcelona. Membre del GREPPS (Grup de Recerca en Pensament Pedagògic i Social). Adreça electrònica: alexegea@ub.edu

(***) Professor del Departament de Teoria i Història de I'Educació de la Facultat d'Educació de la Universitat de Barcelona. Col-laborador del GREPPS (Grup de Recerca en Pensament Pedagògic i Social). Adreça electrònica: ferran.sanchez@ub.edu

(****) Professor del Departament de Teoria i Història de l'Educació de la Facultat d'Educació de la Universitat de Barcelona. Membre del GREPPS (Grup de Recerca en Pensament Pedagògic i Social)Adreça electrònica: jgarciaf@ub.edu 
del que tracta el debat posthumanista, un vessant filosòfic que davant aquests ràpids i vertiginosos progressos es planteja qüestions de caire polític, ètic, econòmic $i$, com no, espirituals. Amb tot, el posthumanisme posa damunt la taula tot un seguit de qüestions que proposen alhora nous reptes per l'educació. També, en conseqüència, el posthumanisme és un discurs que entra en el terreny pedagògic.

Però anem a pams. Per tal de tractar aquest tema amb una certa sistemàtica la primera pregunta que s'ha de respondre és quin és l'origen del debat posthumanista. Acte seguit, vistes breument les arrels, es passarà a analitzar alguns dels temes que s'esbossen al si del debat posthumanista per, finalment, veure els reptes pedagògics i educatius que s'enceten. Així doncs, abans de tot, ens endinsarem en l'origen del discurs transhumanista.

\section{Origen, l'enfocament retro-progressiu biològic-cultural del trans- humanisme}

D'antuvi podríem dir que fa 15.000 milions d'anys s'originà el nostre Univers a partir de la gran explosió que fou el Big Bang. Tan bon punt això passà, ingents quantitats de matèria i energia es desplegaren tot just a l'inici del marc espai-temporal en el que encara ara es dona l'esdevenir del ser humà. L'informe magma caòtic inicial de matèria i energia donà pas a l'estat físic material del plasma, pura potència des-estructurada, fins que aparegueren uns primers dibuixos, signes o missatges còsmics, similars als que encara tracen els mesons atòmics a les cambres quàntiques dels laboratoris científics.

En general, a la natura hi ha moltes formes similars a la prefoliació circinada de les falgueres, planta que probablement hom té com a decoració vegetal d'interior a la seva sala d'estar. Aquestes constitueixen una mena de molla replegada sobre sí que, en créixer, es desplega donant lloc a una fulla esponerosa. Cal recordar que el replegament de fulles de falguera és com un espiral vital, com un etern retorn mai repetit exactament igual, com ara una permutació metafísica que impedeix a Heràclit el bany altra vegada al mateix riu de la vida, també present als capsals dels mànecs dels violins, als bàculs dels bisbes cristians, a les matemàtiques espirals de Fibonacci, a la closca dels Nautiloideus, autèntics fòssils vivents. Potser, fins i tot, també al miracle més gran del llenguatge de la Natura que és la doble hèlix del DNA, molècula informativa biològica que atresora el majúscul secret de l'Univers tot. Com ara la pregunta absoluta, la que conté totes les altres i la que explica el perquè les ments més brillants s'hi han quedat atrapades sorpreses per la seva absoluta bellesa: què és la vida? Interrogació que no només és el títol del llibre del físic Erwin Schrödinger, sinó alhora un símptoma del que seria I'harmonia musical universal, albirada ja pels antics filòsofs grecs en els diversos Periphyseon, o en la relació existent entre matemàtica, música, biologia i filosofia, sinó també per ments de biòlegs tant brillants com la de Jakob von Uexküll.

L'essencial de tot això rau en què no es tracta només d'una escriptura més o menys inspirada respecte tot l'anterior, sinó d'exercir el deure filosòfic que demarca tot l'interrogar característic de la més vella, bella i antiga de totes les disciplines del fet de conèixer. Què és la vida? Es demanarà l'ésser humà des de la biologia. Quin sentit té la vida? Serà la pregunta corresponent a la filosofia i la teologia. Què puc fer amb la meva vida? Què podem dibuixar, com a projecte comú, social, ètic i polític? Serien, probablement, les preguntes que correspondrien no a una pedagogia contaminada del pensiero devole sinó a una disciplina d'estudi que, partint de la història i resseguint els desenvolupaments del 
pensament humanístic i científic, ens ajudaria a orientar la nostra existència. Val a dir que tot estudiós hauria d'esmerçar un gran esforç en atendre les dues línies de pensament que s'inter-fecunden mútuament tot deixant-les hibridar-se naturalment. Nogensmenys, tots els híbrids genètics posseeixen un superior vigor. Per això, no les hem de captenir captives en frames popperians mentals i acadèmics separats, cosa que les mata i a nosaltres ens emmalalteix per desnutrició la vida de l'esperit. Memòria, intel.ligència i voluntat, en suma, tot resseguint el pensament d'aquell geni filosòfic, teològic i pedagògic que fou Sant Agustí.

Llavors, la interrogació sobre el posthumanisme, el transhumanisme i d'altres derivades de la modificació de l'humà per l'humà -sigui de manera més o menys natural, sigui de manera tecnocientífica o cultural- no és que siguin pals a tocar per la pedagogia, sinó que entronquen amb allò que n'és de més radical i per tant que més ens astora o ens produeix basarda a la pedagogia: què en fem de nosaltres mateixos, com arribem a ser allò que potser podem arribar a ser, quin és el nostre grau de llibertat i, per tant de responsabilitat; podem, de debò, acceptar que només som partícules còsmiques, producte de col-lisions atzaroses, mònades o àtoms desproveïts de tot lligam amb el pleroma de la fulla de desenvolupament del llinatge humà (Monod, 2007, p. 31)? No som, per contra, els amos del nostre destí, no som els Vulcans que, Iluny de ser deus otiosus, forgem, a cops de martell, encara que no sigui més que de martell filosòfic nietzschià, el nostre esdevenir, el nostre futur com a individus pertanyents al poble humà, únic i agermanat pel coneixement, sota la immensa magnitud de la sorpresa causada pel cel nocturn estrellat, $i$ el bategar en el nostre pit de la llei moral kantiana?

Havíem deixat l'origen de l'Univers com a primordi, emetent els primers balboteigs còsmics, conseqüència del part recent: el plasma previ a l'emergència del primer àtom de la taula periòdica dels elements químics, contenia tota la matèria, energia i informació de l'Univers, allò que el físic francès Le Moigne anomenà inforgètica. La clau està, doncs, en una poètica química derivada de la inforgètica, no només en el nivell còsmic de l'Univers, sinó també en el fet d'entendre que la vida biològica reestructura aquest principi físic termodinàmic en les macromolècules del DNA i del RNA.

Efectivament, el bauplan del desenvolupament orgànic biològic, en el decurs de l'ontogènia i la filogènia serà un continuum, tot tractant de donar forma a la materialitat existent, incardinar l'essència o ousía dins la mera matèria, per tal que les formes orgàniques despleguin les seves potències, tot resseguint el pensament aristotèlic (Smith, 1977, p. 114). Però, tot fent un plausible salt etimològic, ens interessarà aquí el fet que aquest incardinar serà tant un in cardis, un buscar un carrer principal o cardus que permeti una orientació axiològica o sentit en la ciutat mundana de la vida dels humans, com un in cordis, un captenir o arribar al cor de la qüestió, tot passant pel lloc on els antics pensaven que residia el pensament i per on tot passava, el topos on resideix el conèixer i l'estimar, Veritat, Bellesa i Bondat: el cor, en el nostre cas un cor cordialis, cor pedagògic, seu de la cordialitat de la phyllia grega expressada en diàlegs tals com el platònic Lysis.

En aquest sentit, aquest in cordis serà també un incordi, una fiblada de tàvec socràtic: una pedagogia que pensava l'ésser humà només des dels marges de la condició humana, la determinada només per la cultura, com per exemple l'assumeix Hannah Arendt a La condició humana, trontolla com una jonça empesa pel vent, degut a l'oblit de la naturalesa humana, el fonament biològic subjacent a tot educar. 
Apories rousseaunianes, com la que escindeix en dues fulles separades allò que és, en veritat esforç de cisalla, natura i cultura, queden en l'estat actual del coneixement científic, totalment periclitades. A la condició antropològica d'ésser doblement articulat, com a ésser biològic i com a un arribar a ser humà, o procés d'humanització sobre l'hominització en base a la transmissió del llegat cultural, s'afegirà, en base al desenvolupament, primer, de les ciències físiques i químiques, i, després en la història i filosofia de la ciència, de les ciències biològiques i les seves aplicacions tècniques mèdiques, la possibilitat de que allò humanis retroactiu en una cibernètica de derives metafísiques sobre el mateix esse. Aquesta és la deriva de soca-rel biològica, però de conseqüències metafísiques que s'albira des de la problematització filosòfica d'allò post referit a un determinat humanisme.

Així, una cibernètica d'allò humà, en base al desplegament del concepte d'inforgètica de Le Moigne, junt amb el fet de considerar els avenços en les biotecnologies del DNA, possibilita la modificació de l'home pel propi home, però no en el sentit no exempt de la cerca profitosa de la polèmica de Sloterdijk a Normas para el parque humano, sinó en un sentit més incisiu i fonamentat sòlidament en un coneixement no d'oïdes del corpus del coneixement científic biològic -el de l' Homo suadens (Castro, 2008, p. 211), la derivada que implica l'acció intencional de l'humà sobre l'humà en base al desenvolupament de la interacció dialògica autopoiètica entre la fulla de desenvolupament humana en base a la genòmica inscrita en el DNA i en els gens Hox de desenvolupament embrionari i postembrionari (Watson, 2018, p. 314), i l'epigenòmica o epigenètica que integra tot el món cultural, i l'acció educativa com a motor del canvi de conductes individuals, socials i polítiques (De Rosnay, 2019, p. 152)- sinó també ara en el que seria el cultiu de l'esse en base a la modificació biomèdica dels gens i dels patterns del desenvolupament orgànic dins els límits o llindars permissibles per la fisiologia i l'ecologia.

Aquests processos ja hi eren presents en el món orgànic com mostra, tot prenent com a exemple, l'hidrogen al què fèiem esment en les línies superiors, en una mena d'enginyeria genètica avant la lettre, sense intervenció humana.

Així durant el període Arqueà, fa uns 3000 milions d'anys, s'efectuà el pas des de les formes de vida procariota quimiolitòtrofes -que prenien com a font d'hidrogen el sulfur d'hidrogen $\left(\mathrm{SH}_{2}\right)$ per a les primitives cadenes transportadores d'electrons per tal de generar prou poder reductor en forma de $\mathrm{NADPH}_{2}$, bescanviable per ATP, la moneda energètica del metabolisme cel.lular-, que, per pressió evolutiva, dona lloc a formes bacterianes capaces de construir un Fotosistema I (FS I) capaç d'utilitzar la llum per fer el procés fotosintètic. No obstant, al seu torn, encara aquestes formes, per mitjà d'una mutació per duplicació gènica dels gens de control del desenvolupament anàlegs als Hox dels Chordata Craniata abans esmentats, donaran origen, per mitjà d'una enginyeria genètica natural, al desenvolupament d'un segon fotosistema (FS II) que ara permetrà amplificar el poder energètic, però també inforgètic de la fotosíntesi anoxigènica, tot desenvolupant la fotosíntesi oxigènica, que substitueix com a font d'hidrogen i per tant, com a font del poder reductor per produir ATP, el $\mathrm{SH}_{2}$ per I' aigua, $\mathrm{H}_{2} \mathrm{O}$, la qual cosa alliberarà l'oxigen a l'atmosfera, tot produint-se una extinció de les formes de vida anaeròbiques, avui relictes.

Ara bé, aquesta enginyeria genètica natural formava part de la teleo-dinàmica associada a la mateixa filogènesi, estant a la base, les mutacions dels gens del desenvolupament, juntament amb els processos d'interacció biòtica, tals com la simbiosi i l'endo-simbiosi, en els 'salts evolutius' que puntualment afecten el gradualisme harmònic evolutiu, 
tal com si fossin anàlegs biològics de les grans revolucions culturals humanes, tals com la Revolució industrial, la Revolució Francesa, o les revolucions del pensament, com la Modernitat cartesiana, la Revolució científica del xvii i xviii o, més actualment, les revolucions de la física amb la mecànica ondulatòria del mateix Schrödinger, la mecànica matricial de Heisenberg, la invenció i el desenvolupament d'Internet, o el descobriment de la doble hèlix del DNA per Watson i Crick i les subseqüents derives aplicades en forma de biotecnologies del DNA.

D'aquestes biotecnologies avui disponibles per a la modificació del genoma humà, aquí, per raons d'espai, ens interessen dues, la tècnica d'edició gènica coneguda com a CRISPR (Watson, 2018, p. 316), desenvolupada en la present dècada, i la més antiga fonamentada en les aplicacions de les S.C (stem cells) o cèl.lules mare. Per la seva banda, CRISPR permet, en base a un desenvolupament tècnic descobert originalment en bacteris, l'edició gènica. Dit en altres paraules, copiar, enganxar i retocar, teòricament gairebé qualsevol fragment dels exons del genoma de qualsevol organisme, fet que obre la possibilitat tant de la realització de quimeres genètiques interespecífiques com la possibilitat, ja real, de modificació per edició del genoma d'un organisme gairebé com si fos reescrit a partir del teclat d'un ordinador.

D'aquesta manera, la metàfora maquinista tant pròpia del reduccionisme positivista científic, deixa de ser una metàfora i es converteix en un fet atòmic en el món, com els postulats per Frege, Russell o Wittgenstein en filosofia de la lògica i filosofia del Ilenguatge, respectivament. Precisament es tracta d'un problema de la relació entre llenguatge, món i vida que traspassa el gir lingüístic de Rorty i pertoca a totes les ciències com a objecte d'estudi, la relació entre inforgètica, llenguatge, vida, coneixement i saviesa.

En canvi, pel que fa a l'ús de les cèl-lules mare, es fonamenta en els estudis de regeneració que han estat duts a terme per biòlegs de l'alçada de Hans Driesch a l'Alemanya del XIX-XX en eriçons de mar (Paracentrotus lividus) i en vertebrats com els amfibis urodels. Les cèl.lules mare retenen la totipotencialitat de les cèl.lules embrionàries, tot i pertànyer a un adult o imago. Degut a això, poden expressar el seu desenvolupament cap a gairebé qualsevol llinatge cel.lular, el que implica que poden ser utilitzades per regenerar molts òrgans malmesos en l'individu imago a adult (Watson, 2018, p. 97). Es podria afegir que les cèl-lules mare probablement són cèl-lules pluripotencials en quant a la seva educabilitat epigenètica. Llavors, s'obriria la possibilitat d'educar les cèl-lules pedagògicament, segons tècniques del laboratori de biologia per a la regulació epigenètica de l'expressivitat fenotípica genètica. Això esdevindria un punt d'inflexió on es creuen biologia, pedagogia i filosofia, cap els terrenys de la bioètica, la filosofia de la ciència i la filosofia de la naturalesa. Per dir-ho millor, la pedagogia hauria d'estar present en aquest debat onto-epistemològic.

A diferència dels processos de mutagènesi espontània tals com l'esmentada reduplicació gènica del gen de desenvolupament pel FS II a partir del FS I, les mutacions genòmiques, junt amb les hibridacions interespecífiques i, fins i tot, interorgàniques i inorgàniques, tals com la construcció de quimeres entre éssers biològics i màquines, i inclús modificacions de les intel.ligències humanes, animals i vegetals amb les intel.ligències artificials, les mutacions que a partir d'avui vindran seran certament diferents. 
Cal advertir que això donarà, per part i per pròpia decisió de l'ésser humà, el pas de la teleodinàmica a una teleologia, doncs el procés evolutiu del propi ésser humà estarà sotmès a processos de decisió racional. Com no podia ser d'altra manera, la poesia anirà per davant del pensament científic i filosòfic. Tant és així que el poeta romàntic alemany Hölderlin afirmava que en el perill resideix la salvació. Ens podem plantejar si la teleologia sobre el propi futur humà no derivarà a teologia, en el que la tècnica sotmesa a l'hegemonia del neoliberalisme econòmic no ens estarà prometent una salvació en la que resideix un perill. Un perill que no és altre que el de la hybris grega, el de pensar-se com Dèdal, que podem esmenar la plana a la Natura, o a Déu, sent tots dos -el Deus sive natura del filòsof jueu Spinoza- una unitat simple, única, inefable i indeterminada sempre fora de l'abast comprensiu d'uns éssers que potser confonen allò que es pot fer amb allò que s'ha, o no, de fer. I aquesta és, precisament, la tasca de la pedagogia, educar en valors a partir del tresor pedagògic que és la història del pensament.

\section{Del Transhumanisme al Posthumanisme, un debat actual}

Es pot dir que la crisi derivada de la pandèmia COVID-19 ha posat de manifest la vulnerabilitat humana. Un virus, del qual l'origen és desconegut però de dubtosa mutació natural dels animals als éssers humans, ha estat capaç de posar en evidència les dificultats de les persones, de les societats i de l'economia per conviure amb un agent contagiós tan minúscul i alhora tan letal. La qüestió plantejada en tota aquesta situació és on són els límits de la ciència, de l'experimentació i de la manipulació humana sobre la natura. La situació ha estat paradoxal. A la vegada que el pensament, la biologia i la filosofia es plantegen temes com ara la millora de la humanitat mercès als progressos de les ciències, i en particular de la biotecnologia, tots els sistemes sanitaris del món es veien col-lapsats per atendre la forma més clàssica i tradicional de la medicina, la de restaurar la salut dels pacients davant una patologia o malaltia derivada del contagi per coronavirus. A la fi d'aquesta terrible experiència hem après, entre d'altres coses, que malgrat el discurs tecnocientífic ha explorat noves dreceres i camins, la realitat i la urgència de la situació ens han fet retornar a la tradició, al paradigma de la medicina terapèutica.

No debades, els límits que s'estableixen entre el que seria millora i el terapèutic es dilueixen. Ara que finalment s'ha aconseguit, i s'està administrant, la tan desitjada vacuna de la COVID-19, ens podríem preguntar, com es qüestiona Muñoz González:

\footnotetext{
«¿Sobre qué base decir, por ejemplo, que una vacuna es tan solo un recurso terapéutico y no también uno de mejoramiento, si quien la recibe obtiene una inmunidad que de lo contrario no tendría en su condición natural?...

En cualquier caso, parece plausible seguir hasta cierto punto la intuición del sentido común acerca de que, antes de curar un padecimiento existente, es decir, antes de curar una enfermedad, lo que la vacuna busca realmente es impedir que se la sufra y, vistas así las cosas, ¿no es esto mejorar en cierto modo al individuo que en principio está sano?». (Muñoz González, 2020, p. 150)
}

Aquesta controvèrsia, aquest dilema, és precisament el que aborda el debat transhumanista. En essència, aquest corrent suposa un ampli projecte de millora de la humanitat actual en tots els seus aspectes. És a dir, millorar l'ésser humà en l'aspecte físic, intel·lectual, emocional i moral mercès als progressos de les ciències, i en particular, de les biotecnologies (Ferry, 2017, p. 35). Al marge de la definició, dins el transhumanisme hi ha hagut dues fases o vessants. El primer transhumanisme, de caire més biològic, aposta per la perfectibilitat humana, potencialment infinita, no únicament amb canvis polítics i socials, sinó també a l'ordre de la natura -incloent la natura humana (Ferry, 2017, p. 40). 
Aquest primer transhumanisme -d'origen roussonià o inclús condorcetià- aposta per un perfeccionament sota el principi que el què és pròpiament humà sigui encara més humà (Ferry, 2017, p. 42). Altrament, el gir posthumanista, ja en la segona fase, fa un pas endavant i una aposta més forta, perquè no només defensa la millora de la humanitat actual, sinó la construcció d'una mena d'híbrid entre la persona i la màquina, quelcom així com la creació d'una nova espècie. Un nou individu, en definitiva, que sorgiria amb l'aplicació de la biotecnologia a l'ésser humà i seria, presumptament, més intel.ligent i poderós que aquest.

El cas és que els transhumanistes, o defensors del pothumanisme cibernètic, conceben que el planeta no és només un lloc on viuen i es desenvolupen els organismes biològics, sinó que és un ser viu en sí mateix. El posthumanisme pren el relleu del transhumanisme i dona un pas més ferm i decidit cap el futur tot proposant no només la millora de la humanitat, sinó la superació d'aquesta tant en el pla individual com en el biològic. La posthumanitat suposa la construcció d'una mena d'híbrid que es situa més enllà del que es humà, en un escenari en què l'home queda totalment desplaçat del centre del cosmos. De fet, pràcticament no té res a veure amb l'ésser humà (Ferry, 2017, p. 47)

Tant en la primera versió com en la segona, es concep que la natura humana no és sagrada i, per tant, res impedeix modificar-la, millorar-la o transformar-la. Amb tot, el transhumanisme no neix amb la voluntat de destrucció ni de-construcció de la llibertat o la felicitat humanes. Ans al contrari, el que vol és afavorir-les, multiplicar-les fins a l'infinit. Es situa en un paradigma optimista, que vol rompre amb un passat cruent i sagnant, ple de guerres tant absurdes com incessants. Es tracta de construir un nou ésser i una nova societat més fraterna, més solidaria i, per tant, millorar la nostra natura per tal que millori, en conseqüència, tant l'àmbit social com el polític o cultural.

Tot i que el transhumanisme no és tan radical com el posthumanisme, fa seu el lema de «de l'atzar a l'elecció» (Ferry, 2017, p. 51). Dit en altres paraules, si s'aconsegueix la possibilitat de millorar i reparar els gens patògens, o si es pot millorar la resistència de l'organisme a l'envelliment o millorar o augmentar les capacitats, qui pot negar-se a ferho? Per aquest motiu, Ferry afirma que el transhumanisme planteja quatre ruptures, més o menys radicals, amb les formes tradicionals precedents de l'humanisme. Una primera ruptura és el pas de la concepció terapèutica de la medicina a la concepció optimitzadora de l'ésser humà, un canvi de concepció i de paradigma que suposa i enceta un debat ètic profund. En segon Iloc, Ferry menciona el fet que el pas d'allò «sofert passivament» al control actiu suposa una altra dimensió a escala històrica que ja no és social, política o cultural. La tercera ruptura és que sota els ulls del transhumanisme no existeixen drets naturals vinculats a la natura humana, sigui aquesta la que sigui. Aquest punt és el que qüestionen els crítics tradicionalistes, com ara els filòsofs Fukuyama o Sandel. Finalment, és clar que la millora de la humanitat no únicament es refereix al fet social, polític o cultural, ni solament a la natura externa, sinó a les nostres dades biològiques internes.

Si considerem ara totes aquestes ruptures, s'entén que el posthumanisme neix com un corrent controvertit que planteja dilemes ètics, polítics, socials i espirituals. Tal i com expressa Cortina:

Resulta, pues, de gran relevancia la reflexión ética que se manifiesta cuando se observa el avance de las llamadas tecnologías emergentes: ingeniería genética, nanotecnología, biotecnología, inteligencia artificial, robótica, neurociencia, etc. Todas ellas nos abren posibilidades prometedoras para el desarrollo de la persona y de la sociedad, pero también plantean desafíos éticos muy importantes para el futuro 
de las capacidades humanas y para la dignidad y la libertad de las personas. En este contexto general, debemos plantearnos la interacción entre las altas capacidades, las capacidades comunes y las discapacidades en una sociedad biotecnológica que deseamos que sea inclusiva e integrada por personas singulares, mejores y diversas. (Cortina, 2017, p. 120)

Com s'observa en aquest paràgraf, el transhumanisme navega en un terreny pantanós, ple de posicions a favor i contràries. El corrent posthumanista, com tots els ismes, recull un ventall d'autors, tendències i, fins i tot, disciplines. Només convé recordar, a mode d'exemple, l'esclat de diferents humanismes que hi va haver poc després de la Segona Guerra Mundial: I'humanisme existencialista de Sartre, I'humanisme marxista de Schaff, I'humanisme integral de Maritain, I'humanisme de l'alliberament de Marcuse, I'humanisme cristià de Mounier o l'humanisme post-industrial de Fromm. Com l'humanisme, el posthumanisme és també un corrent de corrents i, per ser rigorosos en el sentit de tot això, hauríem de parlar de posthumanismes. Però, tot i aquesta apreciació, aquí es continuarà parlant amb el singular.

Tanmateix, lluny de qualsevol visió apocalíptica, Albert Cortina defensa les possibilitats que ens obre l'humanisme avançat. Davant aquesta situació de progrés tecnocientífic es tracta de construir un humanisme avançat on les tecnologies emergents es posin al servei de les persones i de la biosfera i no a l'inrevés, que també pot succeir. Per aquest motiu l'ètica, les humanitats i l'espiritualitat, més que mai, han de liderar aquest nou escenari de progrés científic (Cortina, 2017, p. 137). I encara més, també l'educació i la pedagogia.

Si des de la II.lustració, i en particular des de Kant, la humanitat es qüestiona les possibilitats d'una ètica universal, és ara el moment més adient per replantejar-se, segons Cortina, aquest tema. La globalització, aquesta nova era de la civilització, requereix un sistema de valors humanistes revistats que configurin una ètica universal. Una ètica que ha d'estar en consonància amb la llei natural. El gran repte que planteja aquesta societat biotecnològica és la cerca de la felicitat. Davant aquest desafiament, resulta del tot necessari construir i defensar de forma activa postulats com ara el dret a la vida, la dignitat inherent a tota persona, la llibertat, el dret a decidir, la defensa de la integritat física i moral, el respecte i reconeixement de la seva dimensió espiritual, l'equitat i la justícia entre els humans (Cortina, 2017, p. 140). Sigui com sigui, necessitem organitzar una societat inclusiva que capaciti a les dones i els homes de tota condició i edat per a que puguin desenvolupar el seu projecte de vida i assolir la seva realització personal vital per tal d'aconseguir la felicitat. Per això, és important regular aquesta nova situació que pot modificar i alternar la pròpia condició humana.

\section{Compromisos, implicacions i reptes pedagògics davant el posthu- manisme}

Recollint el que s'ha dit anteriorment, el Transhumanisme, l'Humanisme avançat o el Posthumanisme, segons es vulgui dir, ens plantegen un seguit de qüestions ètiques que, indiscutiblement, també ho són filosòfiques, antropològiques, pedagògiques i, com no, educatives. Imaginem-nos, per un moment, un món on la intel-ligència artificial imperés. Un món on els diagnòstics mèdics fossin sobrehumans, on les persones tinguessin vides més llargues, millors i més saludables. Ara bé, resulta lògic i clar, a dia d'avui, que un robot no pot reemplaçar les relacions interpersonals, no sent emocions ni pot trametre-les. Malgrat això, el que sí és possible és construir robots que alleugereixin el treball humà en la 
cura de les persones, per exemple de la gent gran. La qüestió seria, llavors, fins a quin punt resulta adient emprar la intel-ligència artificial o la robòtica per la cura d'una o un pacient o per l'educació d'un infant, o fins a quin punt això pot ser degradant o posar en qüestió la dignitat humana. Novament aquí sorgeix la pregunta d'on i quins són els límits de la intel.ligència artificial.

A propòsit d'aquest fet, Thomas Metzinger, un dels filòsofs més interessats en aprofundir en l'ètica de la intel-ligència artificial, afirma que sembla que s'ha posat en marxa un tren, el tren de la digitalització i de la intel-ligència artificial, però ningú sap d'on surt ni cap a on va, malgrat tothom considera important pujar-se a temps (Metzinger, 2019). Però, com tot, aquest avenç biotecnològic té una cara obscura, un perill latent que ens posa de manifest la necessitat d'afrontar èticament, pedagògicament i educativament aquest terreny. Tot i que els investigadors de la intel-ligència artificial tenen interès en passar a la història com els que han aconseguit millorar el món i la humanitat, també es corre el risc que descobreixin sistemes d'armes letals autònomes, o altres aparells que posin en perill la vida de la humanitat mateixa. S'han construït robots i creat aplicacions què, malgrat no ser una intersecció entre humà i màquina, poden hackejar persones, tot fingint que són éssers humans. A tall d'exemple trobem Google Duplex, un tipus d'intel.ligència artificial que busca automatitzar algunes tasques per l'usuari, com ara reservar un restaurant o trucar a la perruqueria per agafar torn. O Replika, que és una aplicació, una mena de robot amic, que aprèn poc a poc les preferències del seu interlocutor humà. Amb aquesta aplicació l'usuari pot xatejar amb un company o companya imaginari les vint-i-quatre hores del dia tot construint una espècie de versió digital de nosaltres mateixos. Ambdós exemples posen de manifest la importància de donar-li un gir educatiu a aquest discurs controvertit i revolucionari, un vessant pedagògic que pugui orientar la vida de les persones davant els avenços biotecnològics.

En resum, ens trobem davant una situació inèdita, una circumstància en la que els paràmetres de raonament anteriors han quedat obsolets, els criteris precedents no ens serveixen de la mateixa manera a com ens han orientat fins ara. Com afirma Campoy, l'enorme diferència d'aquest moment -en què els paràmetres anteriors o les decisions preses no ens ajuden com a referents- és que «la humanidad se enfreta a la posibilidad cierta de que, fruto de los avances científico-técnicos, pueda o inevitablemente vaya a cambiar al ser humano en características que consideramos tan constitutivas de su esencia como es la mortalidad, la corporeidad o la individualidad" (Campoy, 2020, p. 312). Vistes així les coses, el transhumanisme ens obliga a plantejar-nos qüestions fonamentals, com ara la visió de la història, del cos i la seva relació amb el món, trets essencials de la natura humana. Potser aquesta transformació no implica únicament una millora de les qualitats de l'ésser humà, sinó un complet re-disseny de les seves capacitats, de la seva conducta, de la seva aparença, la seva ment i les seves emocions. Potser, inclús, pot desaparèixer la pròpia espècie a la que ara pertanyem (Diéguez, 2017, p. 197). No obstant, la qüestió que es posa en solfa és per a què tot això, quina és la finalitat. I és aquí on s'obre el debat pedagògic. Si la vida s'allarga, ens hem de comprometre a ajudar als éssers humans a tenir un projecte vital més ampli, en concordança amb la nova finitud. Això implica un discurs teleològic de caire filosòfic alhora que pedagògic i educatiu. Ajudar a les persones a construir i conquerir la seva felicitat en consonància amb un projecte vital, que no solament pot ser individual sinó també social, local, global i holístic. 
El cert és que el posthumanisme representa l'ampliació dels límits i de les fronteres d'allò que es considera propi de ser humà. Sota aquest punt de vista, allò post humà designa, en primer lloc, la necessitat de comprometre's amb una concepció de la condició humana més àmplia, que aglutini característiques que avui en dia es neguen a considerar com humanes (el que es coneix com la hibridació entre l'home i la màquina, persones amb xips al cervell, o millorades genèticament). I, en segon Iloc, comprometre's en la construcció d'un context humanista més ampli (per això, el prefix post- o trans-) que posa la vida al centre del debat: del discurs (la vida de qualsevol ésser viu, incloent el propi planeta).

Alhora, el transhumanisme s'erigeix com un projecte antropotècnic (Muñoz González, 2020, p. 150) que té com a pretensió desplaçar «cap endavant» la frontera del que un membre mitjà de la nostra família humana és capaç de fer. Si això és així, el plantejament educatiu hauria de ser un altre. En altres mots, si les capacitats humanes s'amplien, està clar que hi ha d'haver un gir pedagògic. La pròpia pedagogia ha de plantejar-se com s'ha d'educar una persona amb més capacitats que l'actual, cap a on ha d'anar i per què. Igualment ha de plantejar-se quin són els nous reptes educatius i els propis fins, cap a quina direcció s'ha d'educar. Tot això, alhora, amaga un debat ètic que no només afecta a la biotecnologia, sinó que va més enllà d'aquest terreny. També es plantegen aspectes econòmics, socials, polítics. Pel que fa a les NBIC (nanotectologies, biotecnologies, informàtica, cibernètica) obren un nou món que potser és el final del capitalisme o el naixement del que s'anomena el pas d'una «economia compartida» a I'hipercapitalisme.

En un excel·lent paràgraf d'un article publicat al 2015 a La Tribune, l'economista Charles-Antoine Schwerer relatava aquest trànsit i definia aquest nou paradigma econòmic amb aquestes paraules:

\begin{abstract}
la economía compartida se ha mercantilizado. Lejos de las ideas postcapitalistas de colaboración entre iguales, BlaBlaCar, Airbnb y demás empresas similares han creado un nuevo modelo ultracompetitivo. Estas plataformas de economía compartida se inscriben en la línea de la historia del capitalismo. Hablando en términos marxistas, esta economía (de mercado) compartida acentúa la rentabilidad del capital: un particular utiliza sus propiedades personales (coche o vivienda principal) para ofrecer un servicio de pago a otro particular (alojamiento o transporte). Antes, el precio del trayecto BlaBlaCar bajaba a medida que se llenaba el vehículo, ahora hay un precio fijo por pasajero. Los ingresos aumentan con el número de viajeros: adiós a la lógica inicial de compartir gastos, bienvenidos a la rentabilidad. Airbnb, BlaBlaCar y el difunto UberPop se inscriben en la continuidad histórica del capitalismo: una innovación tecnológica hace emerger nuevos servicios que extienden la esfera mercantil a islotes de gratuidad o de economía informal. BlaBlaCar, Airbnb y UberPop han ampliado, simplificado y monetizado el autoestop, el intercambio de viviendas y los coches compartidos. ¡Estas prácticas, antes informales y marginales, han accedido a toda la extensión de un mercado y ahora implican transacciones financieras! (citat per Ferry, 2017, p. 138)
\end{abstract}

Realment, aquesta situació que Shwerer descriu és la del cost marginal zero que, lluny de significar una pèrdua de diners a les empreses, és el reclam per a que hom consumeixi o sobre-consumeixi. És la lògica del low-cost, però portada a l'extrem. Aquest nou tipus d'economia, l'hipercapitalisme, fa més rentables les propietats privades. En poques paraules, aquestes es tornen en béns mercantilitzats. Tot això ens endinsa en un nou paradigma social que posa en perill les restes que romanen encara de l'estat del benestar social, dels serveis socials i de la protecció social dels col-lectius més vulnerables. Per això, el repte que aquesta situació ens posa sobre la taula és de caire educatiu. Ara, més que mai, ens hem de comprometre com a humanitat per a evitar el desequilibri de forces, els desequilibris socials i culturals que pot provocar aquesta nova era. Per dir-ho d'una altra manera, darrera aquest nou moment, que pot esdevenir un gran pas endavant per a la 
humanitat i un punt d'inflexió en la trajectòria històrica, també es pot amagar una nova conjuntura on la bretxa social, econòmica i cultural encara es faci més insalvable. I això, que embolcalla grans perills, pot suposar una dualitat ontològica, social i econòmica, entre d'altres.

De la mateixa manera, el posthumanisme es configura com un imaginari incert en què diferents escenaris poden esdevenir plausibles. Per una banda, des d'una visió més conservadora, cal apuntar que la configuració d'un món posthumà, en la qual ja estem immersos, implica irremeiablement la superació de la humanitat, i el seu relegament en el transcurs històric dels esdeveniments. Partint d'aquest punt, són diferents les contra argumentacions realitzables al discurs posthumanista, doncs, les seves iniciatives arriben a atemptar contra la condició humana -tenint en compte les incalculables repercussions en la dignitat, Ilibertat o autonomia dels individus. Si bé, tal com apuntava Calvo als anys vuitanta, «la genética moderna nos enseña que el estilo cromosómico es el mismo en toda nuestra especie» (Calvo, 1980, p. 109) i, fins i tot, que «la antigua idea de que los hombres son hermanos no es, pues, tan solo un sentimiento poético o una esperanza de moralistas, sino una realidad objetiva» (Calvo, 1980, p. 109), I'antropotècnica actual i propera serà capaç d'alterar el rumb biològic de l'evolució i bifurcar la nostra espècie (acabant amb la igualtat biològica). Més enllà, tampoc existeix cap certesa que un món posthumà apropi al ser del futur a sentir-se més satisfet amb la seva existència i, per tant, s'apropi més a la plenitud o a l'autorealització. Per acabar-ho d'adobar, no es té cap garantia que el progrés científic es tradueixi també en un avenç ètic i social (que sigui capaç de redistribuir els anunciats beneficis obtinguts) ni que aquest estigui fiscalitzat democràticament.

Per altra banda, una posició més optimista augura que en un context posthumà, l'ésser humà ja no es situarà per sobre del planeta i de la resta d'espècies vives, sinó en una posició d'igualtat respecte elles. És aquí on s'obre la possibilitat d'autoconsciència que indueix l'ésser humà al desenvolupament d'una ètica de la responsabilitat que es concreta en la cura i preocupació per al manteniment i sostenibilitat mediambiental; un tipus d'ètica que s'oposa tant al neoliberalisme -per ser un sistema econòmic que explota els recursos materials i energètics, que agredeix la biosfera contaminant-la i convertint-la en un abocador de residus i que, a més, entén les altres formes de vida des de criteris econòmics i de rendibilitat-com a liberalisme individualista -que produeix un ésser humà egocèntric i egoista amb un estil de vida basat en la producció i el consum il.limitat d'objectes-. La qüestió de dignificar la vida ocupa un lloc central en aquest anar «més enllà de l'humanisme» i el (futur) subjecte posthumà és conscient de la seva responsabilitat en construir espais i relacions solidàries, respectuoses i sostenibles amb les diferents formes de vida.

\section{A tall de cloenda, cap a una pedagogia post-cultural}

Per acabar, un cop realitzat el recorregut pel ventall de possibilitats del transhumanisme i del posthumanisme, podem cloure que és la pedagogia qui ha d'orientar d'antuvi la vida de les persones en aquest nou paradigma. És l'educació la que ha de donar sentit a aquesta evolució i ho ha de fer, com sempre ho ha fet, mitjançant la cultura. Com s'ha vist, els dilemes que es plantegen són, principalment, de caire pedagògic. Malgrat aquesta evolució de l'ésser humà, la pedagogia, tal i com l'entenia Spranger, ha de centrar-se en la cultura -o, al seu torn, en la post-cultura-, atès que la humanitat, o en el seu 
cas, la posthumanitat, haurà de vincular-se entre si, amb el passat i afrontar la incertesa del futur a través d'aquesta, de la cultura. Per aquest autor alemany, la cultura és una estructura supra-individual, un tot organitzat per relacions de valor i d'eficàcia, vinculades de tal mode que donin una unitat d'acció als seus membres per tal que puguin mantenir relacions teleològiques (Spranger, 1935, p. 102).

Davant el repte educatiu que ens planteja el transhumanisme, s'ha d'educar per la post-cultura, entesa com un organisme en contínua transformació, una estructura que uneix als membres que en formen part i els dona una projecció de futur. La post-cultura hauria d'englobar creacions que constitueixen el món espiritual. Precisament en la seva trajectòria històrica es troben els individus entrelligats. La que manté viva aquesta cultura, així com la post-cultura, és l'educació. És la que permet el seu dinamisme. A fi d'educar en i per a un món posthumanista, l'educació s'ha de centrar en la cultura, atès que és aquesta la que permet a la humanitat, o posthumanitat, adaptar-se al nou medi, col.locarlo adientment en aquesta nova situació i emplaçar-lo en la nova realitat, mantenir la societat viva i orientar-se cap a uns fins teleològics. Cal recordar que per a Spranger, la funció educativa de l'escola no només queda emmarcada en els alumnes que hi assisteixen, sinó també en tota la comunitat. Així doncs, es tracta que els béns culturals i post-culturals, els produïts per la humanitat al llarg de la història i dels temps, es transformin en béns formatius, inclosos els valors, els béns materials, les creences, les idees, la ciència, el coneixement, la política, l'estètica, etc. En definitiva, l'escola ha d'ensenyar ara més que mai a pensar, a transformar la realitat sense menystenir el passat ni els avenços culturals que ens han permès conquerir $i$ assolir el que som i el que podem arribar a ser. En cas contrari, el posthumanisme serà un projecte erigit a les palpentes. Encara més, és la pedagogia la que ha d'ajudar a encertir el camí de l'esdevenir de l'ésser humà i del món. Ni més ni menys. 


\section{Referències}

Braidotti, R. (2015) Lo posthumano. Barcelona, Gedisa

Calvo, M. (1980) Las utopías del progreso. Barcelona, Guadarrama

Campoy, I. (2020) «Recensión de Llano Alonso, F. H. Homo excelsior. Los límites éticojurídicos del transhumanismo. Valencia, Tirant lo Blanch, 2018», Cuadernos Electrónicos de Filosofía del Derecho, núm. 42, 2020, p. 310-319.

Castro, L., Castro, L i Castro, M. A. (2008) ¿Quién teme a la naturaleza humana? Homo suadens y el bienestar en la cultura: biología evolutiva, metafísica y ciencias sociales. Madrid, Tecnos.

Cortina, A. (2017) Humanismo avanzado. Para una Sociedad biotecnológica. Madrid, Ediciones Teconté.

De Rosnay, J. (2019) Epigenética. La ciencia que cambiará tu vida. Barcelona, Ariel.

Diéguez, A. (2017) Transhumanismo. La búsqueda tecnológica del mejoramiento humano. Barcelona, Herder.

Ferry, L. (2017) La revolución transhumanista. Cómo la tecnomedicina y la uberización del mundo van a transformar nuestras vidas. Madrid, Alianza Editorial.

Fukuyama, F. (2002) Our posthuman future. Consequences of the biotechnology revolution. New York, Picador

Habermas, J. (2002) El futuro de la naturaleza humana: ¿hacia una eugenesia liberal?. Barcelona, Paidós

Jacob, F. (2005) El juego de lo posible. México, FCE.

Lévi-Strauss, C. (1962) El pensamiento salvaje. México, FCE.

Metzinger, T. (2019) entrevista realitzada a A.A.V.V. (2019) ¿Robocalipsis? Los límites éticos para la inteligencia artificial. DW documentales. https://www.youtube.com/watch?v=sHVwwriaT6k. Consultat el: 02/02/2021

Monod, J. (2007) El azar y la necesidad. Ensayo sobre la filosofía natural de la biología moderna. Barcelona, Tusquets.

Muñoz González, D.M. (2020) «Transhumanismo; un giro de tuerca a la pregunta por la técnica de Heidegger». Estudios de filosofía, núm. 61, p. 145-166.

Ortega y Gasset, J. (1965) Meditación de la técnica. Madrid, Biblioteca Nueva

Sloterdijk, P. (2000) Normas para el parque humano. Madrid, Siruela

Smith, C.U.M. (1977) El problema de la vida. Ensayo sobre los orígenes del pensamiento biológico. Madrid, Alianza editorial.

Spranger, E. (1935) Las ciencias del espíritu y la escuela. Madrid, Publicaciones de la Revista de Pedagogía.

Watson, J. D. (2018) ADN. El secreto de la vida. Madrid, Taurus. 


\section{El posthumanismo, un reto educativo a la vez que pedagógico}

Resumen: Pese a que pudiera parecer osado, se podría afirmar que la humanidad se encuentra ante un hecho inédito. Por primera vez en la historia, las diferentes áreas del saber pueden confluir y encontrar puntos de interconexión que acaben superando los vínculos establecidos por las coordenadas biológicas y culturales que, hasta ahora, han delimitado la condición humana. A saber, las diferentes ciencias naturales, la neurociencia, las ciencias de la información, la robótica, el urbanismo, la biología, etc., gracias al avance tecnológico y la digitalización construyen una cosmovisión capaz de soñar utopías hasta ahora irrealizables. Paradójicamente todo esto, que abre muchas oportunidades, plantea a la vez muchas cuestiones éticas y deja la puerta abierta a nuevos retos pedagógicos. El presente ensayo intenta establecer algunas de las líneas prioritarias que inicia el posthumanismo, desde el punto de vista filosófico y antropológico, pero también desde la vertiente pedagógica y educativa.

Parlabras clave: Biología de la educación, transhumanismo, posthumanismo, Filosofía de la educación, Pedagogía.

\section{Le post-humanisme, un défi à la fois éducatif et pédagogique}

Résumé: Bien que cela puisse paraître audacieux, on pourrait affirmer que l'humanité se trouve devant un fait inédit. Pour la première fois dans I'histoire, les différents domaines du savoir peuvent non seulement converger et trouver des points de connexion entre eux, mais aussi surmonter enfin les liens établis par les coordonnées biologiques et culturelles qui, jusqu'à présent, ont délimité la condition humaine. En effet, les différentes sciences naturelles, la neuroscience, les sciences de l'information, la robotique, l'urbanisme, la biologie, etc., grâce au progrès technologique et à la numérisation, construisent une cosmovision capable de rêver à des utopies jusqu'ici irréalisables. Paradoxalement, tout cela ouvre de nombreuses opportunités, mais soulève en même temps un grand nombre de questions éthiques et laisse la porte ouverte à de nouveaux défis pédagogiques. Cet article vise à établir quelques-unes des lignes prioritaires ouvertes par le post-humanisme, sur les plans philosophique et anthropologique, mais aussi pédagogique et éducatif.

Mots-clés: Biologie de l'éducation, transhumanisme, post-humanisme, philosophie de l'éducation, pédagogie

\section{Posthumanism, an educational and a pedagogical challenge}

Abstract: Although it may seem a bold assertion, it could be said that humanity is in an unprecedented situation. For the first time in history, the different areas of knowledge can come together and find points of interconnection and finally overcome the links established by the biological and cultural coordinates that, until now, have delimited the human condition. Thanks to technological advances and digitization, the various natural sciences, neuroscience, information sciences, robotics, urban planning, biology, and so on are building a worldview able to dream of hitherto unrealizable utopias. Paradoxically, in addition to the many opportunities that this situation offers, it also raises many ethical issues and leaves the door open to new pedagogical challenges. The present paper aims to establish some of the priority lines that start in posthumanism, from the philosophical and anthropological points of view, but also based on pedagogical and educational aspects.

Keywords: Biology of Education, Transhumanism, Posthumanism, Philosophy of Education, Pedagogy. 